\title{
Evaluation and utilization of a kinetic enzyme direct measuring photometer
}

\author{
PAUL L. WOLF \\ From the Division of Clinical Pathology, Department of Pathology, University of California, San Diego, \\ La Jolla, California 92037, USA
}

SYNOPSIS We have recently utilized a prototype model of the Beckman Enzyme Activity Analyzer System-TR in our laboratory measuring various serum enzyme activities which include: alkaline phosphatase (ALP), E.C.3.1.3.1; creatine kinase (CK), E.C.2.7.3.2; hydroxybutyrate dehydrogenase (HBD), E.C.1.1.1.30; lactate dehydrogenase (LD), E.C.1.1.1.27; aspartate transaminase (AST), E.C.2.6.1.1; and alanine transaminase (ALT), E.C.2.6.1.2. Precision was found to be good. Sample activities could be measured as high as $1000 \mathrm{IU} / 1$. The carryover studies fell within $2 \mathrm{SD}$ of the means of the enzyme control studies. Coefficients of variation for ALP and CK were in the ranges of $0 \cdot 40-2 \cdot 14 \%$ and $0 \cdot 52-4 \cdot 30 \%$, respectively. Correlation studies were done with GemSAEC and Gilford $300 \mathrm{~N}$ Spectrophotometer and the results were accurate, precise, and reproducible.

The work load of enzyme determinations in our laboratory has markedly increased in the past few years. Determination of enzyme activity is a most useful diagnostic tool, not only in heart disease but also in diseases of other organs, according to Wolf and Williams (1973). There is an increasing need for reliable, accurate, and precise automated instrumentation for enzyme analyses.

This report describes the capabilities of the Beckman System-TR. Performance studies were done on a prototype model. These studies include precision, linearity, recovery, and correlations with methods existing in the laboratory. To be able to use the Beckman System-TR for routine enzyme analysis we had to evaluate the capability of performance. The evaluation presented here emphasizes the comparison with the GemSAEC and includes studies of precision, range of linearity, and comparison of analytical values between the two instruments.

\section{Materials}

\section{APPARATUS}

The Beckman System-TR is an automated enzyme instrument designed to perform kinetic rate analyses. It is a double-beam instrument and can measure

Received for publication 16 December 1974. absorbances at either $340 \mathrm{~nm}$ or $405 \mathrm{~nm}$ of wavelength. Reaction is monitored on a strip-chart recorder, and the results are printed in International Units per litre at $37^{\circ} \mathrm{C}$.

The instrument was evaluated for the determination of ALP, CK, HBD, LD, AST, and ALT. The rate of analysis was 25 samples per hour for CK to 45 samples per hour for ALP and LD. The throughput for AST and ALT came to 40 samples per hour. The instrument was calibrated at $37^{\circ} \mathrm{C}$.

For correlation studies, the same specimens were assayed for the different enzymes using manual methods on the Gilford 300-N Spectrophotometer with thermocuvette (Gilford Instrument Laboratory, Oberlin, Ohio) and the GemSAEC (ElectroNucleonics, Inc, Fairfield, NJ).

REAGENTS, SAMPLES, AND CONTROLS

We evaluated new enzyme lyophilized controls with three levels of activity-low, medium, and high (Hyland Laboratories, Costa Mesa, Calif). All the reagents needed for an enzyme determination are contained in one bottle ( 20 determinations per bottle) to be reconstituted with deionized water, except for the ALP which has a specific buffer.

The normal ranges were established from healthy blood bank donors, and correlation studies were done on sera of hospital patients. Sera with visible haemolysis were rejected for the study. 


\section{Methods}

The ALP activities were estimated, according to the method of Bowers and McComb (1966), utilizing the substrate p-nitrophenyl phosphate. The CK procedure was a composite of methods of Oliver (1955) and Rosalki (1967). The activity of serum HBD was determined as described by Rosalki and Wilkinson (1960). LD activities were assayed according to the methods of Gay, McComb, and Bowers (1968) and that of Amador, Dorfman, and Wacker (1963). Serum AST activity was assayed according to the method of Amador and Wacker (1962). The activity of ALT was determined according to the method of Henry, Chiamori, Golub, and Berkman (1960). The enzyme determinations performed in this study were done at $37 \pm 0 \cdot 1^{\circ} \mathrm{C}$.

\section{Procedure}

INSTRUMENT OPERATION

The operating instructions provided with the Beckman System-TR were closely followed. A strip-chart recorder was attached to the System-TR for continuous visual monitoring of the reactions.
Results were printed in $\mathrm{IU} / 1$ at $37^{\circ} \mathrm{C}$, preceded by the position number in the turntable (0-19) and the enzyme test being performed. Elevated enzymes were marked with flags to make proper dilutions of specimens.

The changeover from one enzyme test to another was accomplished by priming with air and with the new substrate needed for the next enzyme analysis.

\section{Results}

We analysed 10-12 aliquots of three Hyland Control Sera containing enzymes at various levels of activity to determine the analytical precision obtainable with the System-TR. The results from these analyses are listed in table $\mathrm{I}$.

Accuracy and day-to-day precision were determined by analysing aliquots of the same enzyme controls with the three levels of activity. In addition, we also analysed the commercial controls currently used in the laboratory (Monitrol I, Monitrol II, and SMA Ref.). Results of these studies are shown in tables II and III.

All the substrates were stable when observed over a period of 48 hours as determined by assaying

\begin{tabular}{|c|c|c|c|c|c|c|c|c|}
\hline \multirow[t]{2}{*}{ Test $^{1}$} & \multirow{2}{*}{$\begin{array}{l}\text { No. of Days of } \\
\text { Analysis }\end{array}$} & \multirow{2}{*}{$\begin{array}{l}\text { Av. No. of tests } \\
\text { per Run }\end{array}$} & \multicolumn{4}{|c|}{ IU/I at $37^{\circ} \mathrm{C}$} & \multirow[t]{2}{*}{$C V \%$} & \\
\hline & & & Mean $^{2}$ & & $S D$ & & & \\
\hline \multicolumn{9}{|l|}{ ALP } \\
\hline $12 \mathrm{~A}$ & 15 & 12 & $66-79^{3}$ & 724 & $0 \cdot 70-2-14^{3}$ & $5 \cdot 46^{4}$ & $1 \cdot 06-2 \cdot 71^{3}$ & $7 \cdot 58^{4}$ \\
\hline $13 \mathrm{~A}$ & 10 & 12 & $129-147$ & 141 & $0.88-2.09$ & $7 \cdot 51$ & $0.62-1.45$ & $5 \cdot 32$ \\
\hline $14 \mathrm{~A}$ & 11 & 12 & $219-249$ & 234 & $0.98-4.50$ & $14 \cdot 68$ & $0.40-2 \cdot 07$ & $6 \cdot 27$ \\
\hline \multicolumn{9}{|l|}{ CK } \\
\hline $12 \mathrm{~A}$ & 13 & 10 & $145-173$ & 160 & $2 \cdot 22-4 \cdot 70$ & $15 \cdot 70$ & $1 \cdot 46-4 \cdot 43$ & $9 \cdot 81$ \\
\hline $13 \mathrm{~A}$ & 16 & 10 & $316-375$ & 341 & $3 \cdot 65-9 \cdot 31$ & $27 \cdot 65$ & $1 \cdot 13-2 \cdot 86$ & $8 \cdot 10$ \\
\hline $14 \mathrm{~A}$ & 11 & 10 & $771-929$ & 866 & $4 \cdot 46-21 \cdot 0$ & $43 \cdot 35$ & $0 \cdot 52-2 \cdot 51$ & $5 \cdot 00$ \\
\hline \multicolumn{9}{|l|}{ HBD } \\
\hline $12 \mathrm{~A}$ & 15 & 10 & $214-235$ & 228 & $1 \cdot 98-6 \cdot 47$ & $11 \cdot 61$ & $0.97-2.83$ & $5 \cdot 09$ \\
\hline $13 \mathrm{~A}$ & 15 & 10 & $424-433$ & 430 & $3 \cdot 77-13 \cdot 23$ & $12 \cdot 63$ & $0 \cdot 82-3 \cdot 05$ & $2 \cdot 94$ \\
\hline \multicolumn{9}{|l|}{ LD } \\
\hline $12 \mathrm{~A}$ & 14 & 10 & $121-131$ & 126 & $1 \cdot 22-2 \cdot 30$ & $5 \cdot 46$ & $1 \cdot 01-1 \cdot 85$ & $4 \cdot 33$ \\
\hline $13 \mathrm{~A}$ & 12 & 10 & $216-246$ & 236 & $2 \cdot 33-5 \cdot 40$ & $16 \cdot 38$ & $0 \cdot 77-2 \cdot 82$ & $6 \cdot 94$ \\
\hline $14 \mathrm{~A}$ & 11 & 10 & $390-434$ & 417 & $5 \cdot 21-4018$ & $43 \cdot 35$ & $0 \cdot 37-9 \cdot 98$ & $10 \cdot 40$ \\
\hline \multicolumn{9}{|l|}{$\mathrm{AST}$} \\
\hline $12 \mathrm{~A}$ & 11 & 10 & $81-89$ & 86 & $1 \cdot 25-2 \cdot 37$ & $5 \cdot 12$ & $1 \cdot 41-2 \cdot 80$ & 5.95 \\
\hline $13 \mathrm{~A}$ & 13 & 10 & $166-179$ & 171 & $1 \cdot 09-3 \cdot 15$ & $8 \cdot 53$ & $0 \cdot 61-2 \cdot 49$ & 4.99 \\
\hline $14 \mathrm{~A}$ & 10 & 10 & $267-279$ & 275 & $1 \cdot 58-3 \cdot 68$ & $7 \cdot 51$ & $0 \cdot 59-1 \cdot 25$ & $2 \cdot 73$ \\
\hline \multicolumn{9}{|l|}{ ALT } \\
\hline $12 \mathrm{~A}$ & 11 & 10 & $10-18$ & 15 & $0 \cdot 67-2 \cdot 0$ & $3 \cdot 75$ & $3 \cdot 75-13 \cdot 60$ & $25 \cdot 0$ \\
\hline $13 \mathrm{~A}$ & 11 & 10 & $55-67$ & 59 & $0 \cdot 84-2 \cdot 89$ & $6 \cdot 14$ & $1 \cdot 29-4 \cdot 80$ & 10.41 \\
\hline $14 \mathrm{~A}$ & 10 & 10 & $144-195$ & 176 & $1 \cdot 21-3 \cdot 60$ & $19 \cdot 80$ & $0.68-2.00$ & $11 \cdot 25$ \\
\hline
\end{tabular}

Table I Precision of results for three levels of activity of enzymes in lyophilized sera analysed with the Beckman System-TR

'Enzyme controls with three levels of activity (low, medium, high) were supplied by Beckman Instruments, manufactured by Hyland Laboratories, Costa Mesa, Calif, USA

${ }^{2}$ Precision studies were done over a period of three months. Data of mean, SD and CV are from lowest to highest.

${ }^{3}$ Range of within run mean values, SD, and CV\% over three-month period

Absolute mean, SD, and CV\% of all values derived during three-month period (day-to-day precision) 


\begin{tabular}{|c|c|c|c|c|c|c|c|c|c|c|c|c|c|c|c|}
\hline \multirow[t]{2}{*}{ Enzyme } & \multicolumn{5}{|l|}{ Low } & \multicolumn{5}{|c|}{ Medium } & \multicolumn{5}{|c|}{ High } \\
\hline & $\overline{\mathbf{x}}$ & & $S D$ & $C V$ & $n$ & $\overline{\mathbf{x}}$ & & $S D$ & $C V$ & $n$ & $\overline{\mathbf{x}}$ & & $S D$ & $C V$ & $n$ \\
\hline $\begin{array}{l}\text { ALP } \\
\text { CK } \\
\text { HBD } \\
\text { LD } \\
\text { AST } \\
\text { ALT }\end{array}$ & \begin{tabular}{|r|r|}
71 \\
151 \\
220 \\
120 \\
76 \\
11
\end{tabular} & $\begin{array}{r}74 \\
152 \\
229 \\
122 \\
86 \\
16\end{array}$ & $\begin{array}{l}4 \cdot 25 \\
5 \cdot 81 \\
8 \cdot 84 \\
4 \cdot 87 \\
3 \cdot 60 \\
2 \cdot 28\end{array}$ & $\begin{array}{r}5 \cdot 76 \\
3.81 \\
3.86 \\
3.99 \\
4 \cdot 20 \\
14.06\end{array}$ & $\begin{array}{l}31 \\
15 \\
30 \\
31 \\
32 \\
32\end{array}$ & \begin{tabular}{|r|r|}
137 \\
315 \\
418 \\
241 \\
157 \\
58
\end{tabular} & $\begin{array}{r}141 \\
326 \\
437 \\
237 \\
172 \\
63\end{array}$ & $\begin{array}{r}5 \cdot 51 \\
10 \cdot 34 \\
19 \cdot 25 \\
7 \cdot 30 \\
5 \cdot 95 \\
6 \cdot 00\end{array}$ & $\begin{array}{l}3 \cdot 90 \\
3 \cdot 17 \\
4 \cdot 40 \\
3 \cdot 08 \\
3 \cdot 46 \\
9 \cdot 48\end{array}$ & $\begin{array}{l}32 \\
15 \\
30 \\
31 \\
32 \\
32\end{array}$ & $\begin{array}{l}231 \\
847 \\
\\
437 \\
259 \\
161\end{array}$ & $\begin{array}{l}239 \\
845 \\
\\
424 \\
281 \\
177\end{array}$ & $\begin{array}{r}9 \cdot 39 \\
34 \cdot 33 \\
\\
19 \cdot 34 \\
8 \cdot 20 \\
19 \cdot 60\end{array}$ & $\begin{array}{r}3.92 \\
4.06 \\
\\
4.55 \\
2.92 \\
11.09\end{array}$ & $\begin{array}{l}31 \\
31 \\
32\end{array}$ \\
\hline
\end{tabular}

Table II Statistical analysis of lyophilized enzyme control sera determined on the Beckman System-TR

Figures in bold type are the manufacturer's assigned values.

\begin{tabular}{|c|c|c|c|c|c|c|c|c|c|c|c|c|}
\hline \multirow[t]{2}{*}{ Enzyme } & \multicolumn{4}{|c|}{ Monitrol I unassayed XLT-307 } & \multicolumn{4}{|c|}{ Monitrol II unassayed XPT-513 } & \multicolumn{4}{|c|}{ Dade SMA Ref. DAS-25 AB } \\
\hline & $\overline{\mathbf{x}}$ & $S D$ & $C V$ & $n$ & $\overline{\mathbf{x}}$ & $S D$ & $C V$ & $n$ & $\overline{\mathbf{x}}$ & $S D$ & $C V$ & $n$ \\
\hline $\begin{array}{l}\text { ALP } \\
\text { CK } \\
\text { HBD } \\
\text { LD } \\
\text { AST } \\
\text { ALT }\end{array}$ & $\begin{array}{r}52 \\
36 \\
229 \\
122 \\
28 \\
32\end{array}$ & $\begin{array}{r}5 \cdot 62 \\
4 \cdot 90 \\
12 \cdot 80 \\
7 \cdot 35 \\
2 \cdot 40 \\
4 \cdot 20\end{array}$ & $\begin{array}{r}10 \cdot 88 \\
13 \cdot 78 \\
5 \cdot 62 \\
4 \cdot 08 \\
8 \cdot 55 \\
13 \cdot 13\end{array}$ & $\begin{array}{l}30 \\
13 \\
30 \\
31 \\
28 \\
32\end{array}$ & $\begin{array}{l}321 \\
474 \\
368 \\
369 \\
106 \\
136\end{array}$ & $\begin{array}{r}14.95 \\
27 \cdot 26 \\
20.50 \\
15.04 \\
5.61 \\
12.92\end{array}$ & $\begin{array}{l}4 \cdot 65 \\
5 \cdot 74 \\
5 \cdot 57 \\
4 \cdot 08 \\
5 \cdot 28 \\
9 \cdot 53\end{array}$ & $\begin{array}{l}30 \\
14 \\
30 \\
31 \\
29 \\
32\end{array}$ & $\begin{array}{r}135 \\
79 \\
\\
246 \\
93\end{array}$ & $\begin{array}{r}14.64 \\
8.82 \\
19.99 \\
5.36\end{array}$ & $\begin{array}{r}10 \cdot 81 \\
11 \cdot 12 \\
\\
8 \cdot 11 \\
5 \cdot 74\end{array}$ & $\begin{array}{l}30 \\
14\end{array}$ \\
\hline
\end{tabular}

Table III Summarized results obtained with the Beckman System-TR on three commercial controls ${ }^{1}$ during a three month period

'(Monitrol I, Monitrol II, and Dade SMA Reference; from Division American Hospital Supply Corporation, Miami, Fla 33152)

\begin{tabular}{llllll}
\hline Enzyme & No. of Dilutions & $\begin{array}{l}\text { Maximum Value } \\
\text { Observed }\end{array}$ & Slope & Intercept & $r$ \\
\hline ALT & 21 & 1222 & 1.041 & -6 & 0.999 \\
SGOT & 26 & 1483 & 1.081 & -5 & 0.999 \\
ALP & 26 & 508 & 1.003 & -0.2 & 0.999 \\
LD & 23 & 1524 & 0.986 & 0.70 & 0.970 \\
CK & 20 & 798 & 0.7888 & 3 & \\
\hline
\end{tabular}

Table IV Linearity studies on Beckman System-TR

\begin{tabular}{|c|c|c|c|c|c|c|c|c|}
\hline \multirow[t]{2}{*}{ Test $^{1}$} & \multirow[t]{2}{*}{ No. } & \multirow[t]{2}{*}{$\mathrm{CV}$} & \multicolumn{6}{|l|}{$I U / 1$} \\
\hline & & & Mean & $I S D$ & $\operatorname{Min}$ & $\operatorname{Max}$ & $\begin{array}{l}\text { Range (2SD) } \\
37^{\circ} \mathrm{C}\end{array}$ & $\begin{array}{l}\text { Range }(2 S D)^{2} \\
\text { Converted to } \\
30^{\circ} \mathrm{C}\end{array}$ \\
\hline $\begin{array}{l}\text { ALP } \\
\text { CK } \\
\text { HBD } \\
\text { LD } \\
\text { AST } \\
\text { ALT }\end{array}$ & $\begin{array}{l}67 \\
82 \\
64 \\
75 \\
92 \\
93\end{array}$ & $\begin{array}{l}28 \\
44 \cdot 4 \\
15 \cdot 2 \\
15 \cdot 3 \\
33 \cdot 3 \\
46 \cdot 7\end{array}$ & $\begin{array}{c}70 \\
59 \\
190 \\
120 \\
16 \cdot 5 \\
15\end{array}$ & $\begin{array}{r}19 \cdot 5 \\
26 \cdot 4 \\
28 \cdot 9 \\
18 \cdot 4 \\
5 \cdot 5 \\
7 \cdot 0\end{array}$ & $\begin{array}{r}31 \\
26 \\
113 \\
76 \\
7 \\
3\end{array}$ & $\begin{array}{r}123 \\
136 \\
252 \\
168 \\
33 \\
39\end{array}$ & $\begin{array}{r}34-108 \\
7-112 \\
132-248 \\
83-157 \\
6-28 \\
1-29\end{array}$ & $\begin{array}{c}24-86 \\
2-66 \\
75-141 \\
49-93 \\
3-18 \\
1-19\end{array}$ \\
\hline
\end{tabular}

Table V Normal values established with the Beckman System-TR, determined at $37^{\circ} \mathrm{C}$, and converted to $30^{\circ} \mathrm{C}$

${ }^{1}$ Data obtained from blood bank donors, male and female, aged $18-65$, ostensibly healthy individuals

${ }^{2} 30^{\circ} \mathrm{C}$ values are derived from calibration curves for each chemistry constructed from 100 patient sera assayed at both $37^{\circ}$ and $30^{\circ} \mathrm{C}$

control sera with different levels of activity. Average $\Delta \mathrm{A} / \mathrm{min}$ observed for the substrates were from $0.002 \mathrm{OD} / \mathrm{min}$ for $\mathrm{CK}$ to $0.0013 \mathrm{OD} / \mathrm{min}$ for ALT calculated over a 20 -minute time period.

Carry-over studies were performed using a sequence of two water specimens, two controls with high level of enzyme activity, and two controls with low level of activity. Data accumulated were taken from five separate runs using 50 pairs of control sera and water specimens for each method. The 
water blanks read $0 \pm 3 \mathrm{IU} / 1$ and the control values fell within $\pm 2 \mathrm{SD}$ of the mean assay of the enzymes studied.

Linearity studies were performed utilizing patients' sera with high levels of enzyme activity. Over 20 dilutions were run for all enzymes assayed except HBD. Table IV presents these data.

Recovery studies were performed by analysing

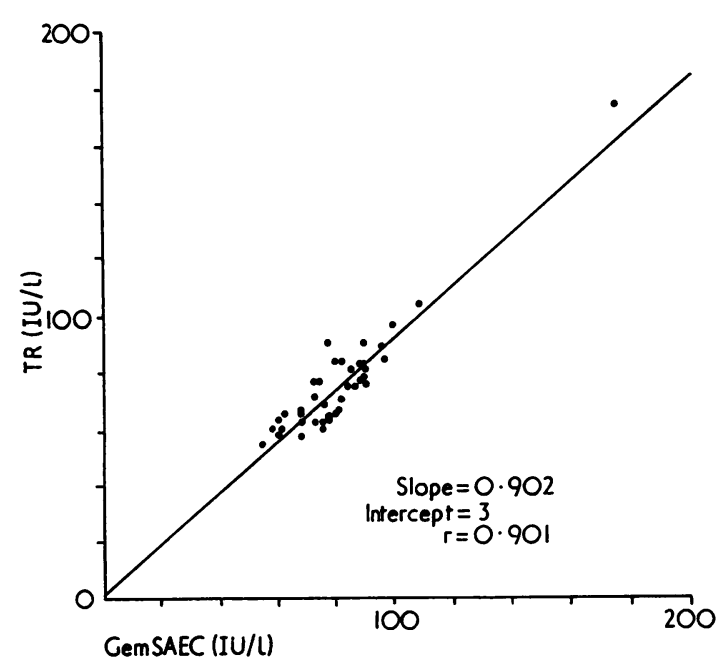

Fig $1 L D$ correlation studies utilizing the same patient's serum specimen correlating the TR $\mathrm{v}$ GemSAEC (iu/l) at $30^{\circ} \mathrm{C}$.

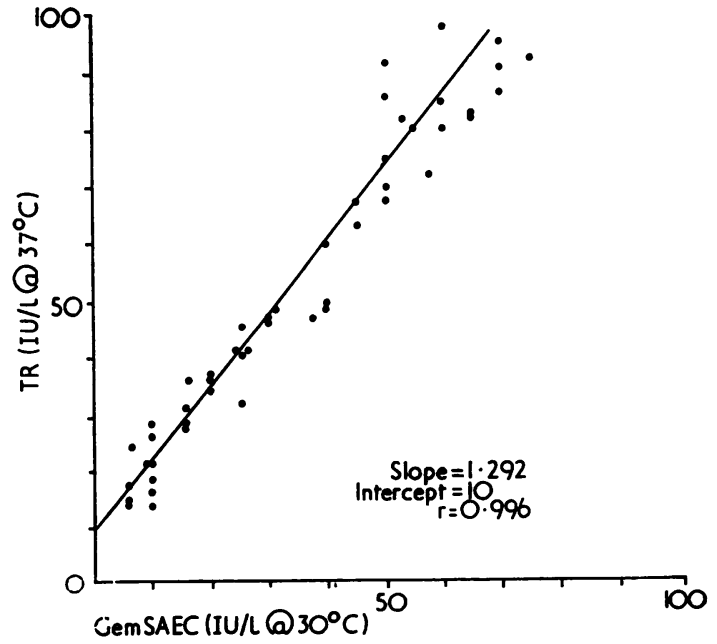

Fig $2 C K$ correlation studies utilizing the same patient's serum correlating the TR $v$ GemSAEC at $30^{\circ} \mathrm{C}$. a series of specimens in which a known amount of enzyme had been added. The amounts of enzymes added ranged from $36 \mathrm{IU} / 1$ of ALP to $358 \mathrm{IU} / 1$ of CK. The average recoveries of the duplicate runs ranged from $95 \cdot 3$ to $106.5 \%$.

The normal values on the six enzyme chemistries were established using healthy blood bank donors. The normal values established with the System-TR

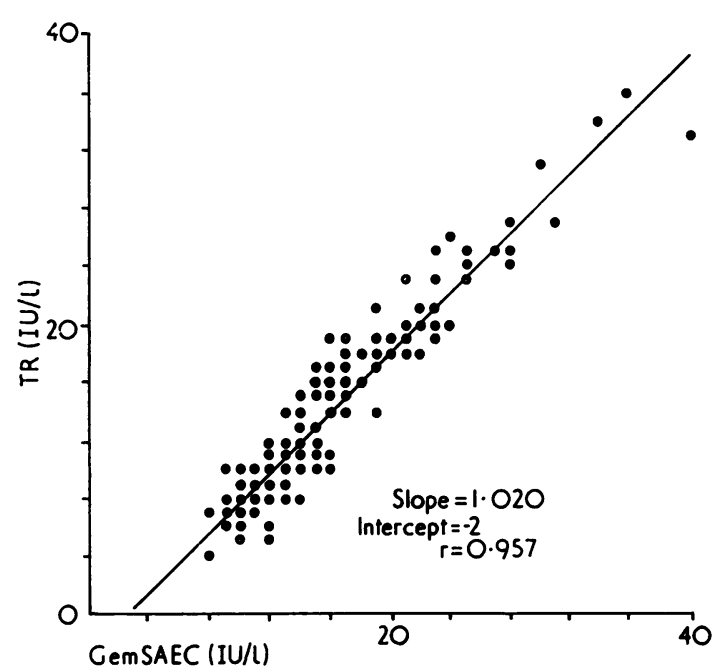

Fig 3 AST correlation studies utilizing the same patient's serum specimen correlating the TR $\vee$ GemSAEC at $30^{\circ} \mathrm{C}$.

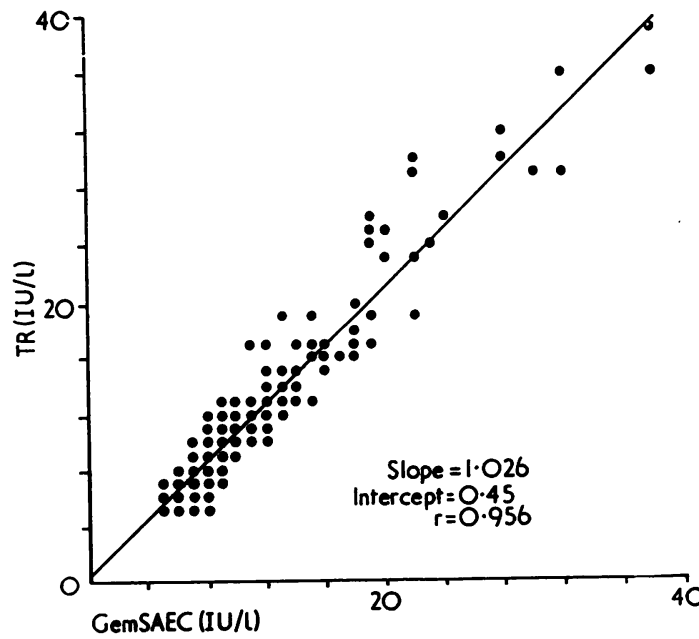

Fig. 4 ALT correlation studies utilizing the same patient's serum specimen correlating the TR $\mathrm{v}$ GemSAEC at $30^{\circ} \mathrm{C}$. 


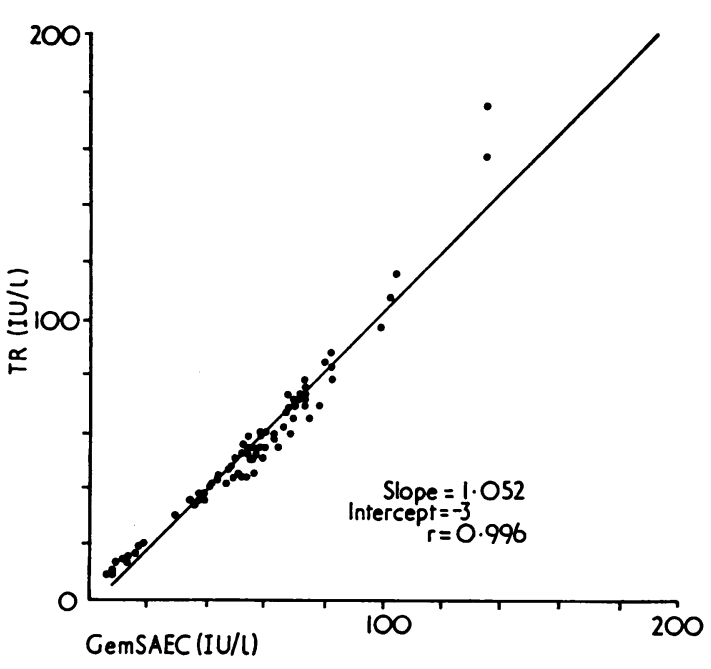

Fig 5 ALP correlation studies utilizing the same patient's serum specimen correlating the TR $\mathrm{v}$ GemSAEC at $30^{\circ} \mathrm{C}$.

agreed well with the normal values previously established in our laboratory. Results are shown in table V.

Correlation studies were performed on the same specimens for the different enzymes using manual methods on the Gilford 300-N Spectrophotometer with thermocuvette and a completely automated instrument, the GemSAEC. Results are shown in figures 1 to 5 .

\section{Discussion}

The throughput of the System-TR is very good for fast enzymes such as ALP and LDH. In addition, the instrument is a versatile one, since the system has a fast and easy test change over. It utilized a one-step pipetting of substrate and specimen, and thus accurate, reproducible, and reliable results are quickly obtained from sample pickup to printout of results.

The results of the precision studies compared well with the GemSAEC. There is no substantial carry-over from samples of high enzyme activities, since there is a rinse cycle between specimen pickup.
The dynamic range and linearity studies demonstrated that dilutions are not necessary up to $1000 \mathrm{IU} / 1$, many times above the normal range. Recoveries are excellent, as evidenced from the data, which would eliminate the possibility of false negative values for enzymes.

Correlation studies with the GemSAEC were very good. Since the results agreed closely between the two instruments, ALP, CK, HBD, LD, AST, and ALT may be measured by either or both instruments in the course of patient treatment.

Our early evaluation of the Beckman-TR found that the loading turntable was easily knocked off with loss of specimen, and a solid base for the turntable was needed. A cover for the turntable was needed to prevent specimen evaporation. The substrate syringe was easily removed from its post. A slight problem with synchronization was also present. All of the deficiencies were corrected after we had made our recommendation.

\section{References}

Amador, E., Dorfman, L. E., and Wacker, W. E. C. (1963). Serum lactate dehydrogenase activity: an analytical assessment of current assays. Clin. Chem., 9, 391-399.

Amador, E. and Wacker, W. E. C. (1962). Serum glutamicoxaloacetic transaminase activity: a new modification and an analytical assessment of current assay technics. Clin. Chem., 8, 343-350.

Bowers, G. N. Jr. and McComb, R. B. (1966). A continuous spectrophotometric method for measuring the activity of serum alkaline phosphatase. Clin. Chem., 12, 70-89.

Gay, R. J., McComb, R. B., and Bowers, G. N. Jr. (1968). Optimum reaction conditions for human lactate dehydrogenase isoenzymes as they affect total lactate dehydrogenase activity. Clin. Chem., 14, 740-753.

Henry, R. J., Chiamori, N., Golub, O. J., and Berkman, S. (1960). Revised spectrophotometric methods for the determination of glutamic-oxalacetic transaminase, glutamic-pyruvic transaminase, and lactic acid dehydrogenase. Amer. J. clin. Path., 34, 381-398.

Oliver, I. T. (1955). A spectrophotometric method for the determination of creatine phosphokinase and myokinase. Biochem. J., 61, 116-122.

Rosalki, S. B. (1967). An improved procedure for serum creatine phosphokinase determination. J. Lab. clin. Med., 69, 696-705.

Rosalki, S. B., and Wilkinson, J. H. (1960). Reduction of alpha-ketobutyrate by human serum. Nature (Lond.), 188, 1110-1111.

Wolf, P. L. and Williams, D. (1973). Practical Clinical Enzymology and Biochemical Profiling, pp. 1-2. WileyInterscience, New York. 